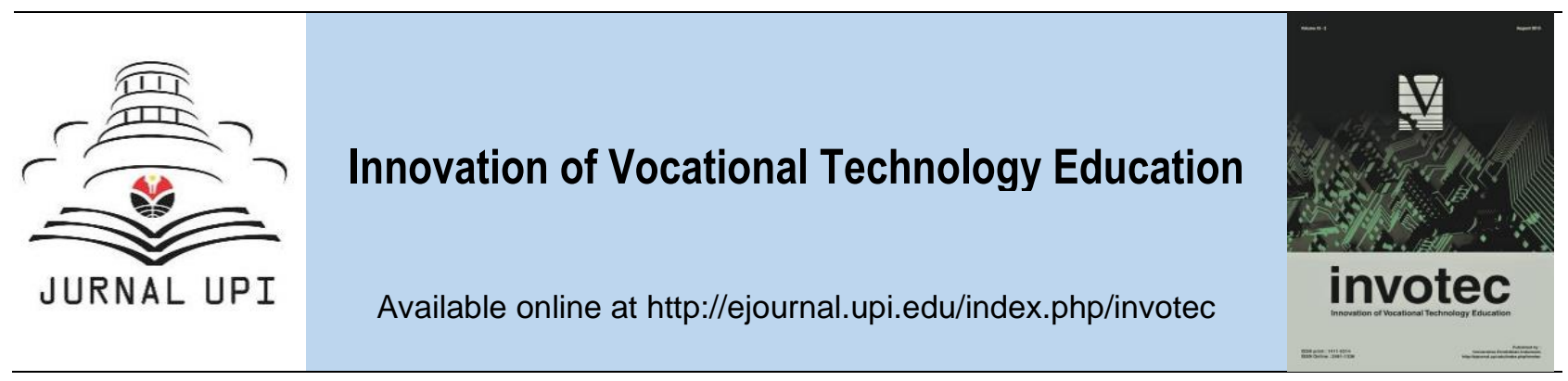

\title{
Effect of Competency, Work Motivation, Industrial Work Experience and Facilities on the Readiness of Work for Senior High School Graduates in Electro Expertise Programs
}

\author{
A. Mustikawanto \\ Universitas Pendidikan Indonesia, Indonesia
}

\section{ARTICLE INFO}

Article history:

Received 17 December 2018

Received in revised form 17 January 2019

Accepted 11 February 2019

Available online 28 February 2019

Keywords:

work motivation, experience of internship,

learning facilities

Corresponding author: abur@gmail.com

\section{A B S T R A C T}

This study aims to determine the effect of competency on vocational readiness readiness, the effect of work motivation on vocational graduates' readiness, the influence of the internship experience on the work readiness, the influence of learning facilities on the work readiness, and the effect of competency, work motivation, internship experience and learning tools together on job readiness. The research method used in this study is by using descriptive research methods with quantitative approaches. The population of this study were all students of the Vocational Electrical Skills Program in West Java Province with sample of 604 students. Data collection uses the questionnaire method or questionnaire. The trial of the research instrument was carried out on students of SMK 1 Katapang as many as 60 students of class XII Industrial Electronics Expertise Program. The results of this study are competence, work motivation, the internship experience, and work practice experience has a positive and significant effect on the work readiness, and competency, work motivation, experience of internship and learning facilities together have a positive and significant effect on work readiness of vocational graduates these four variables together affect work readiness.

\section{Introduction}

Education is very important for a country. In addition to having a big goal to develop the country, efforts to prepare workers, and improve human resources are also very important and needed to meet the needs of the workforce. As one of the educational institutions, Vocational High Schools (Vocational Schools) have an effort to prepare human resources who are ready to use to meet the workforce, in accordance with the program of expertise that their students have (Dahil, et. al., 2015).

Vocational school is formal education that has a special training pattern to direct students to become graduates who are ready to plunge professionally and participate in the business or corporate world (Craig, et. al., 2013). Article 15 of the National Education System Law states that vocational education is secondary education that prepares students to work in certain fields. To support this goal, Dual System Education was designed as an embodiment of link and match between educational institutions and the world of work. This is done in order to create graduates 
who have abilities that are in accordance with the world of work (Kartini and Martono, 2016). Vocational School is an educational institution that makes skilled workers to prepare students to enter the workforce by fulfilling competency in various fields (James and Vincent, 2005). The presence of Vocational Schools in preparing trained workers greatly helps the business world, but not all SMK graduates can meet the needs of the workforce in accordance with the competency of their expertise (Berrin, 2008).

Globalization is defined as a process whereby there will be a flow of people, economic units, goods and services from outside the borders of the world. This definition indicates the principle of openness where the borders between countries are neglected, so that there is freedom for humans, economic units, goods and services to enter/enter a country (Smith, 2010). Furthermore, this definition also implies the existence of equal rights and enforcement for each country (Khalid, 2014). The existence of these developments needs to be anticipated by graduates or the younger generation in order to be able to demonstrate their existence in the era of globalization which inevitably comes soon to hit the country. Therefore, education and vocational education must be able to equip graduates with the material and competencies needed to win the competition (Calhoon and Finch, 1992).

\section{Method}

The research method used in this study is by using descriptive research methods with quantitative approaches. Descriptive methods involve certain phenomena based on observations or explorations of correlations between two or more phenomena. While the quantitative approach is research that explains the phenomenon by collecting numerical data which is analyzed using mathematical methods based on certain statistics. Data in the form of numbers are then described and described in the form of sentences to produce conclusions in the form of statements that can be understood and generally accepted.

\section{Result and Discussion}

The effect of competence on work readiness the vocational graduates of the electrical engineering expertise program show that the higher the competencies students have, the higher their readiness to work and the higher the absorption of labor from electronic expertise competence. Achieving competencies in the learning process is very influential on the high and low achievement of knowledge, psychomotor aspects and student attitudes. Vocational graduates are not only competent enough, but must have character, work culture, religious values and norms, hard skills, soft skills, entrepreneurial character and life skills. The learning process in Vocational Schools must be real learning, real assessment, real job and real life (Rainer, 1996).

Work motivation against work readiness vocational graduates of the electrical engineering expertise program, illustrate that the high motivation of student learning will have an impact on the higher desire for creativity and innovation that students have so as to spur the SMK to improve HR competencies, facilities and activities, both through learning teaching factory, teaching industry, techno park, and so on. The high motivation to learn will have an impact on work motivation, one's work motivation will appear or be seen through the responsibility of doing work, achievement or competence achieved, development of himself and the ability to act (Jeong and Kevin, 2013). Work motivation will also appear to be among them always responsible for all the work they do, always trying to achieve the best work performance, being independent, diligent, broad-minded in the scope of their work, full of creativity and creating innovative work efficiency.

Motivation of student work in vocational students is very important because with high motivation can encourage students to be more active in increasing the provision of good or competent knowledge, skills and work attitudes and industrial culture, students will try optimally to prepare themselves to become workers who are competent in accordance with the competencies they do, so that students are more ready to work and become entrepreneurs.

The influence of employee experience on work readiness vocational graduates of the electroexpertise program in the face of the globalization era in the province of West Java, show that the experience of student internship is very useful in preparing vocational students to enter the workforce. Experience gained during internship can provide real insight into the world of work and entrepreneurship. As long as internship students get real guidance and learning in the industry and 
in the school teaching factory, the knowledge, skills and work attitudes that are obtained will influence the way of thinking, behaving, and behaving in carrying out work. From the mental readiness of students will be personal and the character is trained to always be disciplined, responsible, wise and fast acting in overcoming problems, able to work together and adapt to the work environment (Bakker, et. al., 2008).

The internship experience will provide a full picture of the industry cycle which is directly the application and implementation of the National Mandatory, Regional Mandatory, and Specialization courses in C1, C2 and C3 in accordance with expertise competence. Internship must be adapted to the student skills competence, in the implementation of the mandatory 6 months, adapted to the conditions and facilities of learning infrastructure, preferably in the teaching factory model in schools, which ends the competency test, in order to develop competencies, characters, values and religious norms work culture, soft skills, and hard skills, entrepreneurial character, students (Calvo and Amato, 2015).

Effect of learning facilities on work readiness vocational graduates of the electrical engineering expertise program show that vocational schools must have industry standard learning facilities of at least 75 percent in order to realize learning goals according to expertise competence. The fulfillment of infrastructure facilities will determine the apprenticeship model for vocational students, namely if the learning infrastructure facilities are only fulfilled $25 \%$, the students must be capable of industrial training, if the learning infrastructure is only $50 \%$ fulfilled, students will be dual mode or dual system education, for example 3 days in the industry 3 school days, or 3 months in school and 3 months in the industry, but if the facilities for learning infrastructure have been fulfilled $75 \%-100 \%$, then the apprenticeship should be implemented for 6 months at the School which ends with the competency test. In the teaching factory learning model in schools, students will be more-free to create creativity and innovate significantly by developing character, work culture and entrepreneurial character. Learning infrastructure facilities in industry-standard Vocational Schools must be able to achieve and meet the competencies expected of students and are needed by the world of work and entrepreneurship, so that these infrastructure can have efficient economic value, in addition to fulfilling the learning process to support teaching factory (Ashley and Fall, 2005).

Influence of competence, work motivation, experience of industrial work practices, and learning tools for work readiness vocational graduates of the electrical engineering expertise program, illustrate that vocational students who have appropriate competencies, high work motivation, experience in industrial workshops and factory teaching in schools, supported by optimal infrastructure facilities both to fulfill the learning process, and to be efficient with economic value, it will have a profound effect on work readiness in accordance with the competence of his expertise.

\section{Conclusion}

The following conclusions are obtained: competency has a positive and significant effect on work readiness of SMK graduates electrical engineering program including high category, work motivation has a positive and significant effect on work readiness of SMK graduates electrical expertise program including high category, experience internship has a positive and significant effect on the work readiness of vocational school graduates. The electrical skills program is included in the high category, learning tools have a positive and significant effect on work readiness graduates of the vocational electrical skills program are in the high category. Competence, work motivation, internship experience and learning facilities together have a positive and significant effect on the work readiness of graduates of the vocational electrical skills program, including the high category.

\section{References}

Ashley, B. and Fall, L. T. (2005). Using the port of entry report as a benchmark: Survey results of on the Job Training Among Public Relations internship site managers. Public Relations Review, 31, 301-304.

Bakker, A. B., Schaufeli, W. B., Leiter, M. P., and Taris, T. W. (2008). Work engagement: An emerging concept in occupational health psychology. Work and Stress, 22(3), 187-200. 
Berrin, B. (2008). Employability Competences of Vocational Secondary School Students. Eurasian Journal of Educational Research, 31,17-34.

Calhoon, C. C. and Finch, A. V. (1992). Vocational Education Concept and Operations. California: Wads Worth Publishing Company.

Calvo, R. and Amato, R. D. (2015). A Collaborative Method of Enhancing Internships Evaluation Throught Stakeholders Alignment. Procedia Engineering, 132, 167-174.

Craig. C., et. al. (2013). Making Economic Real: The Economic Internship. International Review of Economics Education, 13, 10-25.

Dahil, L., Karabulut, A. and Mutlu, I. (2015). Reasons and Results of Non-applicability of Education Technology in Vocational and Technical Schools in Turkey. Procedia, Social and Behavioral Sciences, 176, 811-818.

James, A. W. and Vincent, R. J. (2005). Stratification, School Work Linkages and Vocational Education. Social Forces, 84(1), 257.

Jeong, S. Y. and Kevin, R. K. (2013). Cross Cultural Comparison of the Effects of Optimism, Intrinsic Motivation, and Family Relations on Vocational Identity. The Career Development Quarnerly, 61(2), 141.

Kartini, B. A. and Martono, S. (2016). Economic Education Analysis. Economic Education Analysis Journal, 5(1), pp.346-362.

Khalid, N. (2014). Importance of Soft Skills for Industrial Training Program: Employers' Perspective. Asian Journal of Social Sciences and Humanies, 3(4).

Rainer, W. (1996), Employment Prospects and Skill Acquisition of Apprenticeship-Trained Workers in Germany. Industrial and Lanor Rekations Review, 49.

Smith, E. (2010). A Review of Twenty Years of Competency-Based Training in The Australian Vocational Education and Training System. International Journal of Training and Development 14(1). 